NBER WORKING PAPER SERIES

MULTINATIONAL CORPORATIONS AND PRODUCTIVITY CONVERGENCE IN MEXICO

Magnus Blomstrom

Edward N. Wolff

Working Paper No. 3141

NATIONAL BUREAU OF ECONOMIC RESEARCH

1050 Massachusetts Avenue

Cambridge, MA 02138

October 1989

We gratefully acknowledge financial support from the C.V. Starr Center for Applied Economics, New York University and SAREC, Sweden. Excellent research assistance was provided by Maury Gettleman. This paper is part of NBER's research program in International Studies. Any opinions expressed are those of the authors not those of the National Bureau of Economic Research. 
NBER Working Paper \#3141

October 1989

\section{MULTINATIONAL CORPORATIONS AND PRODUCTIVITY CONVERGENCE IN MEXICO}

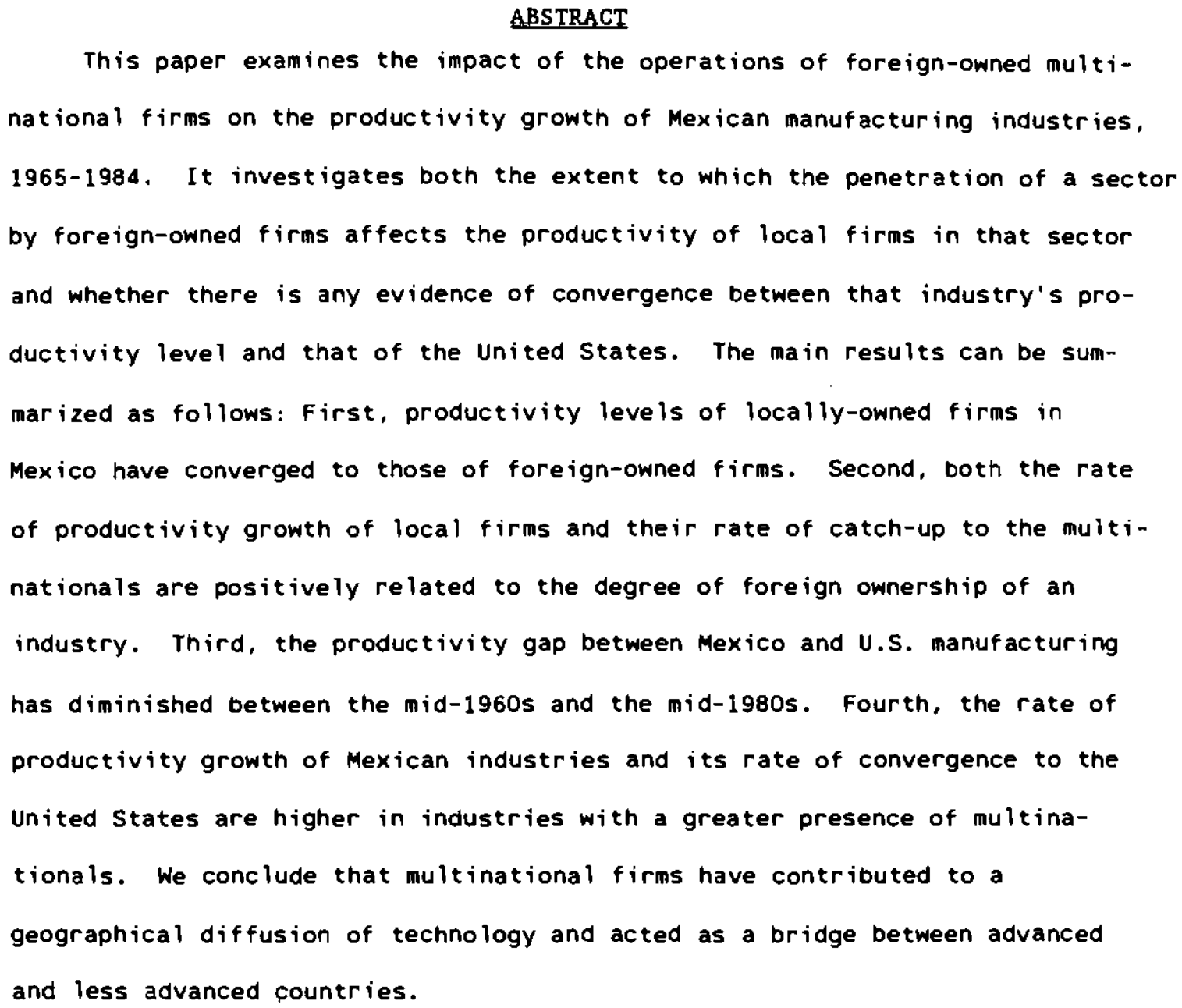

Magnus Blomstrom

Stockholm School of Economics

P.0. Box 6501

11383 Stockholm

Sweden
Edward N. Wolff

Department of Economics

New York University

269 Mercer Street

New York, NY 10003 


\section{Introduction}

An important strand of literature on economic development is the so-called convergence school, based on Gerschenkron's (1952) advantages of backwardness thesis, which has gained currency in recent years. It is argued that a country's potentiality for productivity growth is affected by the relative backwardness of the country vis-á-vis the advanced industrial nations. The more backward the country, the higher the rate of productivity growth achievable by acquiring the technology of the advanced nations. At least among industrialized countries, a strong inverse relation between the rate of productivity growth and the country's initial relative productivity level is indicated from Baumol (1986), Baumol and Wolff (1988), and Wolff (1988) on the aggregate level, and evidence from Dollar, Wolff, and Baumol (1987) and Dollar and Wolff (1988) suggests that these relations also hold on the individual industry level, at least in manufacturing.

With regard to developing countries, there has been almost no work on convergence. Indeed, results from Baumol and Wolff (1988) indicate that as a group, less developed countries (LOCS) have been diverging from the developed countries in terms of productivity over the postwar period. However, the performance among the LDCs has been far from uniform. This indicates that the realization of the potentiality for productivity catch-up simply because of backwardness depends strongly on another set of causes, some of which are internal, others external to the countries themselves (see Abramovitz, 1986). 
Among the external factors that may influence a country's productivity, the multinational corporation (MNC) deserves special attention. In recent times the MNC has become one of the most important agents in the production of technology and it plays a major role in the international diffusion of new technology. However, despite the enormous amount of controversy over the transfer of technology by multinationals, both in their home and host countries, there are no studies dealing with the role of these firms in productivity convergence among countries.

In this paper we examine the impact of the operations of foreign owned multinational firms on the productivity growth of Mexican manufacturing industries. We investigate both the extent to which the penetration of a sector by foreign-owned firms affects the productivity of local firms in that sector and whether there is any evidence of convergence between that industry's productivity level and that of the United States. Thus, we concentrate on intra-industry influences and focus primarily on external effects or "spillovers" of foreign direct investment.

A few earlier studies have tried to test for the existence of such technology spillovers (e.g. Blomström, 1989, Caves, 1974, and Globerman, 1979), and they all found some support for the spillover benefit hypothesis. However, because of great methodological difficulties in investigating these effects, and a relative paucity of data, none of these studies was able to analyze the nature of spillover efficiency in any depth. Furthermore, none of them tried to evaluate the importance of such spillovers for productivity growth in the host country.

The remainder of the paper has two major sections: the first focuses on 
the productivity spillovers between domestic and foreign firms in Mexico and the second on Mexico's international catch-up. There is also a brief summary section at the end.

II. Convergence between foreign and local firms in Mexico

\section{A. Multinationals, Technology Transfer, and Convergence}

The convergence hypothesis asserts that when the productivity level of one (or several) country(ies) is substantially superior to that of a number of other economies, largely as a result of differences in their productive techniques, then those laggard countries that are not too far behind the leaders will be in a position to embark upon a catch-up process. This catch-up process will continue so long as the economies that are approaching the leader's performance continue to have the possibility of learning from the leader. However, as the distance between the two groups narrows, the stock of knowledge unabsorbed by the laggards will grow smaller and approach exhaustion. The catch-up process will then tend to terminate unless some supplementary and unrelated influence fortuitously comes to play. Meanwhile. those countries that are so far behind the leaders that it is impractical for them to profit substantially from the leaders' knowledge will generally not be able to participate in the convergence process at all, and many such economies will find themselves falling even further behind.

The most important influence underlying this hypothesis is the transfer of technology that constantly takes place among economies. Technology may be transferred from one place to another through a variety of channels, but in the postwar period, the multinational corporations have become the most 
powerful institution for the spread of new technology. Multinational firms not only establish subsidiaries abroad, but they also transfer technology through a number of other arrangements, including licensing, franchising. management contracts, marketing contracts, and technical service contracts.

Subsidiary production, or what we might call foreign direct investment, is still the dominant mode in which multinational firms exploit their intangible assets in foreign markets, and there are several ways in which such investment may facilitate diffusion of technology from advanced to developing countries. One is simply that the multinationals set up operations in developing countries that are beyond the technological capabilities of host country firms. Even if there is no leakage of the technology to local firms, there would still be a geographical diffusion of technology, but without any change in its ownership.

Technology transfer through foreign direct investment can also result in indirect productivity gains for host developing countries through the realization of external economies. Generally these benefits are referred to as "spillovers", which indicates the importance of the way in which the influence is transmitted. There are several ways in which these spillovers may occur. Presumably the most important channel is via competition (see Blomstróm, 1986). Existing inefficient local firms may be forced by the competition of foreigners to make themselves more productive by investing in physical or human capital or importing new technology.

Another source of gain to the host economy is the training of labor and management provided by the multinationals, which may then become available to the economy in general. Since such resources are in a short supply in 
developing countries, this type of spillover efficiency is expected to be more important there.

A third potential source of spillover efficiency benefits is through the impact made by the foreign subsidiaries in the host economy on their local suppliers, by insisting that they meet standards of quality control, delivery dates, prices, etc. This aspect should be particularly important in countries like Mexico, where legislation requires domestic content.

While all these influences would cause positive long run effects on host country productivity there are, to be sure, also several offsetting forces at work. First, technology transfer within multinationals is far from free (see Teece, 1976). It involves a substantial commitment of real resources and a sequence of overlapping stages of activities. This will slow down the technology transfer process and make multinationals unwilling to share information. Second, the technology that is used by the MNC may be inappropriate for local firms in developing countries, because of the relative factor proportions that they face. Both of these positions would suggest little technology spillover between the MNC and the local firms in the country. Third, Lall (1980) argues that imports of technology through foreign investment may work as an important first injection to local technologica! development, but that too much reliance on foreign technology may retara the basic design and development activity in the host country, causing negative long run effects on productivity.

To determine whether the presence of MNCs acts as a catalyst or a hindrance to the productivity growth in Mexico we begin by investigating productivity convergence among foreign and local firms in Mexican manufac- 
turing industries. For that purpose we use unpublished data from the Mexican Census of Manufactures 1970 and 1975 (see Appendix). These are the only two years for which data by ownership are available. Though the period is unfortunately short, the results are nonetheless quite strong. We first investigate trends within 20 broad manufacturing industries, and then perform a regression analysis. ${ }^{1}$

\section{B. Aggregate Trends}

It is clear from Table 1 that, in 1970, foreign firms displayed higher labor productivity than Mexican firms. The productivity of foreign firms, measured both in value-added and gross output, was more than 2 times that of local firms on average. Among Mexican firms, labor productivity was significantly higher in state-owned than in privately-owned firms, although the state companies were not as efficient as the affiliates of the multinationals.

To a large extent, the differences in labor productivity can be explained by differences in the firms' capital intensity. This can be seen in Table 2, which shows the firms' capital-labor ratio as a fraction of the overall capital labor-ratio of the industry. The capital intensity was 2.5 times higher in foreign firms than in the privately-owned Mexican, but, interestingly, about the same as in the state-owned firms. However, the greater efficiency of multinationals relative to both state-owned and privately-owned firms in Mexico still holds for total factor productivity (TFP). As Table 3 indicates, the foreign firms' TFP measured in gross output was 34 per cent higher than that of local firms on average, with the difference being highest in tobacco (150 per cent higher), petroleum (138 per 
cent), rubber ( 89 cent), and transport equipment (78 per cent). In lumber and wood products, chemicals, and miscellaneous manufacturing, local firms' TFP exceeded that of the multinationals.

However, the data in Table 4 indicate that Mexican firms caught up with the multinationals over time. Between 1970 and 1975, the multinationals' productivity lead in terms of labor productivity diminished in the manufacturing sector as a whole, as well as in three-fourths of the individual manufacturing industries. There was also a tendency towards convergence in total factor productivity over the same period, but these figures should be interpreted with great caution, since the capital stock figures for 1970 and 1975 are not directly comparable (see the Appendix).

In sum, we find rather large productivity differences between foreign and local firms in Mexico, but that the foreign firm's lead has been diminishing. To examine whether this productivity catch-up is related to the presence of multinationals and the existence of spillovers between foreign and local firms, we will now relate the latter productivity growth to the presence of foreign firms in various industries.

\section{Regression Analysis}

Two regression forms are used. The dependent variable, in the first, is the rate of productivity growth of local firms within an industry, and, in the second, it is the rate of convergence in labor productivity levels between local and foreign firms within a sector. These variables are related to the degree of foreign ownership of the industry and the gap in labor productivity between local and foreign-owned firms in 1970, as well as two other explanatory 
variables.

As Table 5 shows, the results are consistent in the two regression forms. Both productivity growth in local firms and productivity convergence between local and foreign firms are faster in industries with a greater share of employment accounted for by multinationals. ${ }^{2}$ Mexican firms' productivity growth and the rate of catch-up to the MNCs are also higher in sectors where the initial disparity in productivity levels between local and foreign firms is greater, a result which accords well with the advantages of backwardness thesis. Furthermore, in sectors with higher capital-labor ratios, the productivity growth of locally-owned firms and the rate of catch-up are lower. This suggests that spillover gains from the new technology of multinationals are easier to incorporate when the investment requirements are small. Finally, convergence seems to be faster in industries with slower output growth, but output growth does not affect the rate of productivity growth of local firms. This suggests that the competitive pressures from the presence of multinationals in an industry is greater in relatively stagnant industries. In rapidly-growing sectors, inefficient local firms can continue to survive without improving their productivity, but in slow-growing industries, the inefficient local firms could be driven out by the multinationals. ${ }^{3}$

The results so far suggest that there exist technology spillovers from foreign direct investment, with a resulting convergence in productivity between foreign and local firms in Mexico, but are these spillover benefits large enough to generate an international catch-up? We now turn to this question by looking at the extent to which there has been a convergence of labor productivity levels between Mexico and the United States. 


\section{International catch-up?}

\section{A. Aggregate Trends}

We begin by comparing the productivity levels of foreign and domestic firms in Mexico with those of the United States in $1970 .{ }^{4}$ As Table 6 shows, foreign firms were very close to the U.S., both in terms of labor productivity and TFP, while local firms in Mexico were far behind. The MNCs' labor productivity and TFP both averaged 93 per cent that of the United States, and in several industries they even exceeded the U.S. levels. Labor productivity in Mexican firms, on the other hand, averaged only 39 per cent of the United States. However, the technology gap, as measured by TFP, was smaller, at 60 percent, which reflects the considerably higher capital intensity of U.S. production. The productivity levels for foreign and local firms taken together correspond rather well with those reported in Maddison and van Ark (1989).

The finding that the foreign affiliates were so close to the United States in terms of productivity while local firms were lagging behind, certainly suggests that multinational firms have contributed to a geographical diffusion of technology and acted as a bridge between advanced and less advanced countries. But is this international diffusion of technology enough for an international catch-up? Table 7 presents the convergence in productivity between Mexico and the United States 1970-1975. Overa11, there seems to be no catch-up going on over the 5-year period, but it varies a lot among industries. In seven industries the U.S, productivity lead diminished, wnile it increased in 13 industries. Results on convergence are similar for the 2-digit industry sample which includes only 4-digit Mexican industries with 
MNCs present, though, as expected, the Mexican productivity figures are higher. This is suggestive. Since foreign participation varies among industries it may very well be that foreign investment is related to international catch-up in one way or another. We will come back to this question below in our regression analysis.

With data from the United Nations we were able to examine the convergence of labor productivity between Mexico and the United States between 1965 and 1984 (Table 8)..$^{6}$ During this longer period there was a clear convergence of productivity levels in all industries for which data are available. The biggest catch-up took place during the second half of the 1960 s, but slowed down thereafter. Between 1970 and 1975 there was very little convergence, just as the census data in Table 7 suggested.

\section{Regression Analys is}

Since the main purpose of this study is to analyze the role of MNCs in productivity convergence among countries, we will, finally, by regression analysis, try to go deeper into that question by relating a sectors' productivity catch-up to the degree of foreign ownership. As mentioned above, there are both direct and indirect effects on total industry productivity of foreign direct investment. The direct effect is that an increase in the share of multinationals in an industry will increase the productivity level of the whole industry, simply because MNCs have higher productivity than local firms. The indirect effect, on the other hand, is the technological spillover between the multinationals and the local firms. Because of data availability for the pre-1970 and the post-1975 period, these two effects cannot be separated in 
the regression.

As before, two regression forms are used. The dependent variable, in the first, is the rate of productivity growth of Mexican industries (local plus foreign firms), and, in the second, it is the rate of convergence in labor productivity levels between Mexican and U.S. industries. These variables are related to the degree of foreign ownership of an industry in Mexico and the initial Mexican-U.S. productivity gap. Both foreign ownership and the initial productivity gap are significantly related to productivity growth within the Mexican industry and its speed of catch-up to the corresponding U.S. productivity level (see Table 9). This holds for both the longer 1965-77 and 1965-84 period, as well as the shorter 1970-75 period. ${ }^{7}$ The capital-labor ratio is again significant and negative for productivity growth in Mexico, suggesting that catch-up with the United States is faster when the investment requirements are lower. Finally, output growth is here statistically insignificant.

IV. Conclusion

Four principal findings emerge from this study. First, productivity levels of locally-owned firms in Mexico have converged on those of foreignowned firms. Second, both the rate of productivity growth of local firms and their rate of eatch-up to the multinationals are positively related to the degree of foreign ownership of an industry. Third, the productivity gap between Mexico and U.S. manufacturing has diminished between the mid-1950s and the mid-1980s. Fourth, the rate of productivity growth of Mexican industries and its rate of convergence to the United States are higher in industries with 
a greater presence of multinationals. The results support the advantages of backwardness thes is in two senses: first, between more advanced and more backward countries and, second, between more modern and more backward segments of an industry.

The results also suggest that local firms in Mexico have gained productivity "spillovers" from the presence of multinational firms in the Mexican economy. However, there is another possibility, namely, that competitive pressure from multinationals forces out the inefficient local firms. This is consistent with the finding that convergence between local and foreign firms is faster when output growth is lower, though this finding might also be due to greater efficiency gains of local firms during periods of slack demand. With the data at hand, we cannot distinguish between these two possibilities. There is strong evidence that the presence of multinational firms acts as a catalyst to the productivity growth in Mexico and that foreign direct investment speeds up the convergence process between Mexico and the United states. However, the available data do not allow us to say whether this is due to productivity "spillovers" or simply to the fact that MNCs are more productive than Mexican firms. Although we could not reject the spillover benefit hypothesis, the productivity convergence between Mexico and the United States might also be due, wholly or in part, to the direct effect of foreign investment. This possibility is strengthened by the finding that the productivity levels of the foreign affiliates in Mexico were very close to those in the United States, while the Mexican firms were lagging far behind. Thus, an increase in the share of multinationals within an industry will increase the level of productivity within the total Mexican 
industry, without any productivity growth among local firms. Furthermore, the importance of this direct effect is strengthen by the fact that the largest catch-up effect was registered between 1965 and 1970 , a time when Mexico received a large injection of foreign investment. 8

In general, we conclude that multinational firms have contributed to a geographical diffusion of technology and acted as a bridge between advanced and less advanced countries. 
Footnotes

10ata on the proportion of output and employment accounted for by foreign firms in Mexican manufacturing industries are provided in Blomstrom (1989).

2Results are similar for the share of industry output accounted for by MNCS.

3This "excise effect" will be explored more fully in a later paper. Regressions were also performed on the 4-digit industry level. The results were similar, but less robust, probably because of the greater noise in the data at the more disaggregated level.

${ }^{4}$ As indicated in the footnote of Table 6 , the exchange rate was used to convert Mexican pesos to U.S. dollars. See Maddison and van Ark (1989) for a discussion.

It should be noted that this period is atypical, since 1975 was a recession year in Mexico, but not in the United States.

${ }^{6}$ Compared to the data used earlier, the UN data are based on samples of firms. Most likely, large firms are over-represented in the sample data, since they show higher labor productivity than do the Census data (compare figures in Tables 7 and 8). An interesting question for future research is, therefore, whether only parts of the Mexican industry (the "modern" part) is converging, while others (the "traditional" sector) are not. Such a pattern was suggested in Blomström (1986), and should be examined further.

${ }^{7}$ The fact that the results are slightly weaker for the 1965-84 period than for the 1965-77 period is likely due to the effects of the debt crisis on Mexican productivity performance after 1982. 
8. We know that the United States dominates the foreign investment activities in Mexico. For instance, the U.S. Department of Commerce reports that in 1977. U.S. multinationals employed 302,000 people in Mexican manufacturing industries. The closest year for which Mexican data are available is 1975 . and then all foreign firms in manufacturing employed 312,549 people. Between 1966 and 1977, the employment in U.S. majority-owned affiliates in Mexico increased from 102,000 to 171,000 (there are no data on minority-owned affiliates for 1966). 


\section{REFERENCES}

Abramovitz, Moses, "Catching Up, Forging Ahead, and Falling Behind," Journal! of Economic History, Vo1. 46, June 1986, 385-406.

Baumo 1, William J., "Productivity Growth, Convergence, and Welfare: What the Long-Run Data Show," American Economic Review, Vol. 76, Dec, 1986, 107285.

Baumo 1, William J., and Edward N. Wolff, "Productivity Growth, Convergence, and Welfare: Reply," American Economic Review, Vol. 78, December, 1988. $1155-9$

Blomström, Magnus, "Foreign Investment and Productive Efficiency: The Case of Mexico," Journal of Industrial Economics, Vo1. 55, September, 1986 , $97-110$

Blomström, Magnus, Foreign Investment and Spillovers: A Study of Technology Transfer to Mexico, (London: Routledge), 1989.

Caves, Richard, "Multinational Firms, Competition, and Productivity in Host Country Markets," Economica, Vol. 41, 1974, 176-83.

Dollar, David, Edward N. Wolff, and William J. Baumol, "The Factor Price Equalization Model and Industry Labor Productivity: An Empirical Test Across Countries," in R. Feenstra, (Ed.), Empirical Methods for International Irade, (Cambridge, Mass.: M.I.T. Press), 1987.

Dollar, David, and Edward N. Wolff, "Convergence of Labor Productivity Among Industrial Countries, 1963-1982," Review of Economics and Statistics, Vol. 70, November, 1988, 549-58.

Gershenkron, Alexander, "Economic Backwardness in Historical Perspective," 
in Bert F. Hoselitz, (Ed.), The Progress of Underdeveloped Areas, (Chicago: University of Chicago Press), 1952.

Globerman, Steven, "Foreign Direct Investment and 'Spillover' Efficiency Benefits in Canadian Manufacturing Industries," Canadian Journal of

Economics, Vol. 12, No. 1, 1979, 42-56.

La11, Sanjaya, "Developing Countries as Exporters of Industrial Technology," Research Policy, Vol. 9, 1980, 24-52.

Maddison, Angus, and Bart van Ark, "International Comparisons of Purchasing Power, Real Output, and Labour Productivity: A Case Study of Brazilian, Mexican, and U.S. Manufacturing," Review of Income and Wealth, Series 35, No. 1, March, 1989, 1-30.

Teece, The Multinational Corporation and Resource Cost of International Iechnology Transfer, (Cambridge, Mass.: Ballinger Publishing Co.), 1976. Wolff, Edward N., "Capital Formation and Productivity Convergence," mimeo, 1988. 
Table 1

Comparison of Labor Productivity Levels Between

Foreign and Domestic Firms in Mexico, 1970"

\begin{tabular}{|c|c|c|c|c|c|c|c|c|}
\hline \multirow[b]{4}{*}{ Industry } & \multicolumn{8}{|c|}{$\begin{array}{l}\text { Productivity Level by Segment as a Fraction of } \\
\text { The Overall Productivity Level of the Industry }\end{array}$} \\
\hline & \multicolumn{4}{|c|}{ Value Added per Employee } & \multicolumn{4}{|c|}{ Gross Output per Employee } \\
\hline & \multirow[b]{2}{*}{ MNC } & \multicolumn{2}{|c|}{ Locally-Owned } & \multirow{2}{*}{ Dotal $_{\text {Domest. }}$} & \multirow[b]{2}{*}{ MNC } & \multicolumn{2}{|c|}{ Locally-Owned } & \multirow{2}{*}{$\begin{array}{c}\text { Total } \\
\text { Domest. }\end{array}$} \\
\hline & & State & Private & & & State $\operatorname{Pr}$ & vate & \\
\hline 20-Food & 2.19 & 0.78 & 0.85 & 0.84 & 2.12 & 0.79 & 0.86 & 0.85 \\
\hline $21-$ Tobacco & 1.17 & - & 0.16 & 0.16 & 1.16 & - & 0.19 & 0.19 \\
\hline 22-Textile Mill & 1.43 & 0.62 & 0.96 & 0.94 & 1.38 & 0.60 & 0.97 & 0.95 \\
\hline 23-Appare 1 & 2.48 & 1.75 & 0.95 & 0.96 & 2.31 & 1.92 & 0.95 & 0.96 \\
\hline 24-Lumber \& Wood & 2.41 & 1.42 & 0.92 & 0.95 & 2.58 & 1.13 & 0.93 & 0.94 \\
\hline 25-Furniture & 1.41 & 1.85 & 0.94 & 0.97 & 1.10 & 1.93 & 0.95 & 0.99 \\
\hline 26-Paper & 1.33 & 1.51 & 0.87 & 0.91 & 1.52 & 1.22 & 0.83 & 0.86 \\
\hline $\begin{array}{l}27 \cdot \text { Printing \& } \\
\text { Publishing }\end{array}$ & 2.00 & 0.99 & 0.95 & 0.95 & 1.72 & 0.86 & 0.97 & 0.97 \\
\hline 28 -Chemicals & 1.28 & 0.94 & 0.75 & 0.77 & 1.17 & 1.20 & 0.82 & 0.86 \\
\hline 29-Petroleum \& Coal & 2.04 & 1.63 & 0.54 & 0.74 & 1.87 & 1.60 & 0.60 & 0.78 \\
\hline 30-Rubber \& Plastics & 2.50 & $\cdots$ & 0.65 & 0.65 & 2.36 & $\cdots$ & 0.68 & 0.68 \\
\hline 31 -Leather & 1.87 & 1.36 & 0.98 & 0.98 & 1.70 & 3.36 & 0.98 & 0.98 \\
\hline $\begin{array}{l}\text { 32-Stone, Clay \& } \\
\text { Glass }\end{array}$ & 1.74 & 0.88 & 0.90 & 0.90 & 1.84 & 0.81 & 0.89 & 0.88 \\
\hline 33-Primary Metals & 1.13 & 1.13 & 0.79 & 0.92 & 1.16 & 1.11 & 0.78 & 0.91 \\
\hline 34-Fabricated Metals & 1.51 & 3.70 & 0.87 & 0.89 & 1.42 & 4.22 & 0.89 & 0.91 \\
\hline 35-Non-Elec. Equip. & 1.47 & 1.54 & 0.75 & 0.76 & 1.59 & 2.21 & 0.68 & 0.69 \\
\hline 36-Electric Equip. & 1.49 & - & 0.74 & 0.74 & 1.47 & - & 0.75 & 0.75 \\
\hline 37-Transport Equip. & 1.37 & 1.07 & 0.62 & 0.75 & 1.53 & 1.06 & 0.47 & 0.65 \\
\hline 38 -Instruments & 1.54 & $\cdots$ & 0.75 & 0.75 & 1.68 & - & 0.69 & 0.69 \\
\hline 39-Miscel. Manuf. & 1.45 & $\cdots$ & 0.90 & 0.90 & 1.25 & -- & 0.95 & 0.95 \\
\hline Total Manuf. & 1.88 & 1.33 & 0.75 & 0.79 & 1.85 & 1.53 & 0.75 & 0.80 \\
\hline
\end{tabular}

a. Basic data are from worksheets provided by la Dirección de Estadistica de la Secretaria de Industria y Commercio in Mexico. See the Appendix for details.

b. Industries are classified by U.S. SIC code and include all four-digit SICs in each industry. See the Appendix for detailed Mexican industry codes included in each U.S. SIC code.

c. The total domestic sector is defined as the sum of state-owned and privately-owned firms, a separation which is available only for 1970 . 
Table 2

Comparison of Capital-Intensity Levels Between Forelgn and Domestic Firms in Mexico, 1970a

\begin{tabular}{|c|c|c|c|c|}
\hline \multirow[b]{2}{*}{ Industry } & \multicolumn{4}{|c|}{$\begin{array}{l}\text { Capital-Labor Ratio by Segment as a Fraction of } \\
\text { The Overall Capital-Labor Ratio of the Industry }\end{array}$} \\
\hline & MNC & State & Private & Domestic ${ }^{c}$ \\
\hline 20-Food & 2.06 & 2.32 & 0.75 & 0.86 \\
\hline 21-Tobacco & 1.13 & - & 0.37 & 0.37 \\
\hline 22-Textile Mill & 1.48 & 0.58 & 0.95 & 0.94 \\
\hline 23-Apparel & 2.48 & 1.62 & 0.95 & 0.96 \\
\hline 24-Lumber \& Wood & 4.67 & 1.24 & 0.84 & 0.87 \\
\hline 25-Furniture & 1.14 & 1.50 & 0.97 & 0.99 \\
\hline 26-Paper & 1.61 & 2.95 & 0.69 & 0.83 \\
\hline $\begin{array}{r}27-\text { Printing } \& \\
\text { Publishing }\end{array}$ & 2.33 & 1.44 & 0.92 & 0.94 \\
\hline 28-Chemicals & 1.28 & 1.33 & 0.70 & 0.76 \\
\hline 29-Petroleun \& Coal & 1.01 & 1.36 & 0.92 & 1.00 \\
\hline 30-Rubber \& Plastics & 1.95 & $\cdots$ & 0.78 & 0.78 \\
\hline 31 -Leather & 2.45 & 1.59 & 0.96 & 0.96 \\
\hline $\begin{array}{l}32 \text {-Stone, Clay } \& \\
\text { Glass }\end{array}$ & 1.75 & 0.65 & 0.90 & 0.89 \\
\hline 33-Primary Metals & 1.10 & 0.92 & 0.96 & 0.94 \\
\hline 34-Fabricated Metals & 1.66 & 3.52 & 0.84 & 0.86 \\
\hline 35-Non-Elec. Equip. & 1.65 & 3.69 & 0.63 & 0.66 \\
\hline 36-Electric Equip. & 1.43 & - & 0.77 & 0.77 \\
\hline 37-Transport Equip. & 1.31 & 1.25 & 0.60 & 0.79 \\
\hline 38 -Instruments & 2.25 & $\cdots$ & 0.43 & 0.43 \\
\hline 39-Miscel. Manuf. & 1.62 & $\cdots$ & 0.87 & 0.87 \\
\hline Total Manuf. & 1.85 & 1.85 & 0.73 & 0.80 \\
\hline
\end{tabular}

a. Basic data are from worksheets provided by la Dirección de Estadistica de la Secretaria de Industrla y Commercio in Mexico. See the Appendix for detalls. The 1970 capital stock figures are based on capital invertido.

b. Industrles are classified by U.S. SIC code and include all four-digit SICs in each industry. See the Appendix for detalled Mexican industry codes included in each U.S. SIC code.

c. The total domestic sector is defined as the sum of state-owned and privately-owned firms, a separation which is avallable only for 1970 . 
Table 3

Comparison of TFP Levels Between

Foreign and Domestic Firms in Mexico, $1970^{\circ}$

TFP Level by Segment as a Fraction of

The Overall TFP Level of the Industry

\begin{tabular}{|c|c|c|c|c|c|c|c|c|}
\hline \multirow[b]{3}{*}{ Industry } & \multicolumn{4}{|c|}{ Value Added Index } & \multicolumn{4}{|c|}{ Gross Output Index } \\
\hline & \multirow[b]{2}{*}{ MNC } & \multicolumn{2}{|c|}{ Locally-Owned } & \multirow{2}{*}{ Tomest. } & \multirow{2}{*}{$\operatorname{MNC~} \stackrel{I}{\mathrm{I}}$} & \multicolumn{2}{|c|}{ Locally-Owned } & \multirow{2}{*}{$\begin{array}{c}\text { Total } \\
\text { Domest. }\end{array}$} \\
\hline & & State & Private & & & State Pr & vate & \\
\hline 20-Food & 1.29 & 0.42 & 1.02 & 0.93 & 1.25 & 0.42 & 1.03 & 0.94 \\
\hline 21 -Tobacco & 1.05 & - & 0.35 & 0.35 & 1.05 & - & 0.42 & 0.42 \\
\hline 22-Textile Mill & 1.14 & 0.80 & 0.98 & 0.98 & 1.10 & 0.77 & 0.99 & 0.98 \\
\hline 23 -Apparel & 1.37 & 1.31 & 0.97 & 0.98 & 1.28 & 1.43 & 0.98 & 0.98 \\
\hline 24-Lumber \& Wood & 0.82 & 1.26 & 1.00 & 1.02 & 0.87 & 1.00 & 1.01 & 1.01 \\
\hline 25-Furniture & 1.31 & 1.45 & 0.95 & 0.98 & 1.03 & 1.52 & 0.97 & 1.00 \\
\hline 26-Paper & 0.98 & 0.71 & 1.06 & 1.01 & 1.12 & 0.57 & 1.02 & 0.95 \\
\hline $\begin{array}{l}\text { 27-Printing \& } \\
\text { Publishing }\end{array}$ & 1.20 & 0.81 & 0.99 & 0.98 & 1.04 & 0.70 & 1.01 & 1.00 \\
\hline 28-Chemicals & 1.08 & 0.77 & 0.93 & 0.90 & 0.99 & 0.99 & 1.01 & 1.01 \\
\hline 29-Petroleum \& Coal & 2.03 & 1.28 & 0.58 & 0.74 & 1.86 & 1.25 & 0.64 & 0.78 \\
\hline 30-Rubber \& P1astics & 1.57 & -- & 0.75 & 0.75 & 1.49 & - & 0.79 & 0.79 \\
\hline 31 - Leather & 1.10 & 1.05 & 1.00 & 1.00 & 1.00 & 2.61 & 1.00 & 1.00 \\
\hline $\begin{array}{l}\text { 32-Stone, Clay } \& \\
\text { Glass }\end{array}$ & 1.22 & 1.09 & 0.95 & 0.95 & 1.29 & 1.01 & 0.94 & 0.94 \\
\hline 33-Primary Metals & 1.07 & 1.20 & 0.81 & 0.96 & 1.09 & 1.17 & 0.80 & 0.94 \\
\hline 34-Fabricated Metals & 1.11 & 1.56 & 0.95 & 0.97 & 1.04 & 1.78 & 0.97 & 0.99 \\
\hline 35-Non-Elec. Equip. & 1.07 & 0.61 & 0.95 & 0.94 & 1.16 & 0.87 & 0.86 & 0.86 \\
\hline 36-Electric Equip. & 1.20 & - & 0.85 & 0.85 & 1.18 & $\cdots$ & 0.86 & 0.86 \\
\hline 37-Transport Equip. & 1.16 & 0.93 & 0.81 & 0.85 & 1. 30 & 0.92 & 0.61 & 0.73 \\
\hline 38-Instruments & 0.92 & -- & 1.09 & 1.09 & 1.00 & $\cdots$ & 0.99 & 0.99 \\
\hline 39-Miscel. Manuf. & 1.11 & -- & 0.97 & 0.97 & 0.96 & -- & 1.01 & 1.01 \\
\hline Total Manuf. & 1.24 & 0.87 & 0.90 & 0.90 & 1.22 & 1.01 & 0.90 & 0.91 \\
\hline
\end{tabular}

a. Basic data are from worksheets provided by la Direccion de Estadistica de la Secretaria de Industria y Commercio in Mexico. The 1970 capital stock figures are based on capital invertido. TFP is measured as a ratio of an industry's output $Y$ to a weighted average of employment ( $L$ ) and capital stock (K):

$\mathrm{TFP}-\mathrm{Y} /[\alpha \mathrm{L}+(1-\alpha) \mathrm{K}]$

where $a$ is the industry's wage share.

b. Industries are classified by U.S. SIC code and include all four-digit SICs in each industry. See the Appendix for detailed Mexican industry codes included in each U.S. SIC code.

c. The total domestic sector is defined as the sum of state-owned and privately-owned firms, a separation which is available only for 1970 . 
Table 4

Productivity Convergence Between Foreign and Domestic Firms in Mexico, 1970-75.

\begin{tabular}{|c|c|c|c|c|c|c|c|}
\hline \multirow[b]{3}{*}{ Industry } & \multicolumn{7}{|c|}{$\begin{array}{l}\text { Ratio of Productivity Levels Between } \\
\text { Domestic Firms and Foreign Firms }\end{array}$} \\
\hline & \multirow{2}{*}{$\begin{array}{l}\text { Value } \\
\text { Added per } \\
\text { Employee } \\
1970\end{array}$} & \multicolumn{2}{|c|}{$\begin{array}{l}\text { Gross } \\
\text { Output per } \\
\text { Employee } \\
\end{array}$} & \multicolumn{2}{|c|}{ IFP } & \multicolumn{2}{|c|}{$\begin{array}{l}\frac{\text { 4-Digit Ind, }}{\text { With MNCs }} \\
\text { Gross } \\
\text { Output per } \\
\text { Employee }\end{array}$} \\
\hline & & 1970 & 1975 & 1970 & $19 \overline{75}$ & 1970 & 1975 \\
\hline 20-Food & 0.39 & 0.40 & 0.50 & 0.75 & 0.54 & 0.48 & 0.59 \\
\hline $21 \cdot$ Tobacco & 0.14 & 0.16 & $\cdots$ & 0.40 & $\cdots$ & 0.16 & - \\
\hline 22-Textile Mill & 0.66 & 0.69 & 0.65 & 0.89 & 0.87 & 0.79 & 0.64 \\
\hline 23-Apparel & 0.39 & 0.42 & 0.71 & 0.77 & 1.36 & 0.42 & 0.32 \\
\hline 24-Lumber \& Wood & 0.39 & 0.37 & 0.44 & 1.16 & 1.19 & 0.36 & 0.44 \\
\hline 25 -Furniture & 0.69 & 0.90 & 0.53 & 0.97 & 0.71 & 0.91 & 0.53 \\
\hline 26 -Paper & 0.68 & 0.56 & 1.02 & 0.85 & 0.79 & 0.56 & 1.02 \\
\hline $\begin{array}{l}\text { 27-Printing \& } \\
\text { Publishing }\end{array}$ & 0.48 & 0.56 & 0.76 & 0.96 & 0.86 & 0.56 & 0.76 \\
\hline 28-Chemicals & 0.60 & 0.73 & 0.69 & 1.02 & 0.84 & 0.75 & 0.70 \\
\hline 29-Petroleum \& Coal & 0.36 & 0.42 & 0.59 & 0.42 & 0.69 & 0.53 & 0.64 \\
\hline 30-Rubber \& Plastics & 0.26 & 0.29 & 0.46 & 0.53 & 0.93 & 0.29 & 0.46 \\
\hline 31 -Leather & 0.52 & 0.58 & 0.72 & 1.00 & 1.16 & 0.59 & 0.73 \\
\hline 32-Stone, Clay \& Glass & 0.52 & 0.48 & 0.57 & 0.72 & 0.84 & 0.52 & 0.62 \\
\hline 33-Primary Metals & 0.81 & 0.78 & 0.79 & 0.87 & 0.75 & 0.78 & 0.79 \\
\hline 34-Fabricated Metals & 0.59 & 0.64 & 0.68 & 0.95 & 1.00 & 0.64 & 0.68 \\
\hline 35-Non-Elec. Equip. & 0.52 & 0.44 & 1.04 & 0.74 & 1.09 & 0.44 & 1.06 \\
\hline 36-Electric Equip. & 0.49 & 0.51 & 1.13 & 0.73 & 1.23 & 0.51 & 1.13 \\
\hline 37-Transport Equip. & 0.55 & 0.42 & 0.36 & 0.57 & 0.45 & 0.43 & 0.36 \\
\hline 38 -Instruments & 0.49 & 0.41 & 0.54 & 0.99 & 1.36 & 0.49 & 0.57 \\
\hline 39-Miscel. Manuf. & 0.62 & 0.76 & 0.66 & $1: 06$ & 1.01 & 0.76 & 0.68 \\
\hline Total Manuf. & 0.42 & 0.43 & 0.61 & 0.75 & 0.79 & 0.47 & 0.64 \\
\hline
\end{tabular}

a. Basic data are from worksheets provided by la Dirección de Estadistica de la Secretaria de Industria y Commercio in Mexico. The TFP figures are based on gross output in each year, but for 1970 the capital stock figures are based on capital invertido, while for 1975, they are based on activos fijos brutos. Since the two concepts differ, comparisons based on the TFP figures in columns four and five of the table should be interpreted with caution. See the Appendix for details.

b. Industries are classified by U.S. SIC code. The results in the first five columns are based on all four-digit SICs in each industry. The results in the last two columns are based on only the four-digit SICS in which MNCs are present in either 1970 or 1975. See the Appendix for detailed Mexican industry codes included in each U.S. SIC code. 
Table 5

Regression Analysis of Productivity Catch-Up between Foreign and Locally-Owned Firms in Mexico*

Dependent Variable:

\begin{tabular}{|c|c|c|c|c|}
\hline Independent & \multicolumn{4}{|c|}{ Dependent Variable: } \\
\hline Varlables & LPGLOC & LPGLOC & LPGLOC & CONVLF \\
\hline Constant & $\begin{array}{r}-0.048 \\
(1.52)\end{array}$ & $\begin{array}{l}0.147^{\star} \\
(2.94)\end{array}$ & $\begin{array}{c}0.172^{*} \\
(3.47)\end{array}$ & $\begin{array}{l}0.219^{*} \\
(3.06)\end{array}$ \\
\hline FORSHARE & $\begin{array}{l}0.351^{*} \\
(3.59)\end{array}$ & $\begin{array}{l}0.245^{* *} \\
(3.34)\end{array}$ & $\begin{array}{c}0.372^{* *} \\
(4.06)\end{array}$ & $\begin{array}{l}0.734^{\circ *} \\
(5.53)\end{array}$ \\
\hline LFLPGAP70 & & $\begin{array}{c}-0.318^{*} \\
(4.35)\end{array}$ & $\begin{array}{c}-0.313^{*} \\
(4.24)\end{array}$ & $\begin{array}{l}-0.446^{\circ} \\
(4.18)\end{array}$ \\
\hline OUTPGRTH & & & $\begin{array}{r}-0.188 \\
(0.89)\end{array}$ & $\begin{array}{c}-0.166^{*} \\
(5.41)\end{array}$ \\
\hline KL1970 & & & $\begin{array}{r}.0 .482^{\circ} \\
(2.15)\end{array}$ & $\begin{array}{r}0.709^{\circ} \\
(2.18)\end{array}$ \\
\hline $\begin{array}{l}\mathrm{R}^{2} \\
\overline{\mathrm{R}}^{2} \\
\text { Std. Err } \sigma\end{array}$ & $\begin{array}{l}0.42 \\
0.38 \\
0.078\end{array}$ & $\begin{array}{l}0.72 \\
0.69 \\
0.055\end{array}$ & $\begin{array}{l}0.79 \\
0.73 \\
0.051\end{array}$ & $\begin{array}{l}0.80 \\
0.75 \\
0.074\end{array}$ \\
\hline Sample S1ze & 20 & 20 & 20 & 20 \\
\hline
\end{tabular}

a Estimated coefficients are shown together with the absolute value of the t-statistic in parentheses. Key:

LPGLOC: annual rate of growth of gross output per employee in locally owned firms, 1970-75.

FORSHARE: share of employment in foreign-owned firms in total 1ndustry employment, averaged between 1970 and 1975 .

LFLPGAP70: ratio of gross output per employee in local firms to gross output per employee in forelgn firms, 1970.

OUTPGRTH: average annual rate of growth of Industry output, 1970-1975.

KL1970: Industry capital-labor ratio in 1970.

CONVLF: rat1o of LFLPGAP75 to LFLPGAP70.

- Basic data are from worksheets provided by la Direccion de Estadistica de la Secretarla de Industria y Commercio in Mexico. Industries are classified by 2-digit U.S. SIC code and include all four-digit SICs in each industry. See the Appendix for details.

* Significant at the .05 level (two-talled test).

* Significant at the .01 level (two-talled test). 
Table 6

Mexican Productivity Level by Segment and Industry As a Proportion of U.S. Productivity Level by Industry, 1970*

\begin{tabular}{|c|c|c|c|c|c|c|}
\hline \multirow[b]{2}{*}{ Industry } & \multicolumn{3}{|c|}{$\begin{array}{l}\text { Value Added per } \\
\text { Employee }\end{array}$} & \multicolumn{3}{|c|}{ TFP } \\
\hline & MNC & Domestic & Total & MNC & Domestic & Total \\
\hline 20-Food & 0.94 & 0.36 & 0.43 & 1.05 & 0.64 & 0.71 \\
\hline $21-$ Tobacco & 0.45 & 0.06 & 0.39 & 0.46 & 0.15 & 0.43 \\
\hline 22-Textile Mill & 1.09 & 0.72 & 0.76 & 1.17 & 0.95 & 0.98 \\
\hline 23-Apparel & 1.65 & 0.64 & 0.67 & 0.65 & 0.51 & 0.51 \\
\hline 24-Lumber \& Wood & 0.69 & 0.27 & 0.29 & 0.50 & 0.43 & 0.43 \\
\hline 25 - Furniture & 1.03 & 0.71 & 0.73 & 0.82 & 0.62 & 0.63 \\
\hline 26-Paper & 0.84 & 0.57 & 0.63 & 0.92 & 0.85 & 0.87 \\
\hline 27-Printing \& Publishing & 0.82 & 0.39 & 0.41 & 0.64 & 0.48 & 0.49 \\
\hline 28-Chemicals & 0.85 & 0.51 & 0.66 & 1.15 & 0.87 & 1.01 \\
\hline 29-Petroleum \& Coal & 0.48 & 0.17 & 0.24 & 1.15 & 0.42 & 0.57 \\
\hline 30-Rubber \& Plastics & 1.66 & 0.43 & 0.67 & 1.76 & 0.71 & 1.00 \\
\hline 31 - Leather & 0.97 & 0.51 & 0.52 & 0.50 & 0.47 & 0.47 \\
\hline 32-Stone, Clay\& Glass & 0.79 & 0.41 & 0.46 & 0.85 & 0.59 & 0.63 \\
\hline 33-Primary Metals & 0.76 & 0.62 & 0.67 & 1.07 & 0.94 & 0.99 \\
\hline 34-Fabricated Metals & 0.55 & 0.33 & 0.37 & 0.58 & 0.46 & 0.48 \\
\hline 35-Non-Elec. Equip. & 0.66 & 0.34 & 0.45 & 0.57 & 0.47 & 0.52 \\
\hline 36-Electric Equip. & 1.10 & 0.54 & 0.73 & 0.96 & 0.66 & 0.79 \\
\hline 37-Transport Equip. & 0.73 & 0.40 & 0.53 & 0.78 & 0.55 & 0.65 \\
\hline 38-Instruments & 0.87 & 0.42 & 0.56 & 0.42 & 0.56 & 0.48 \\
\hline 39-Miscel. Manuf. & 0.51 & 0.32 & 0.35 & 0.51 & 0.42 & 0.44 \\
\hline Total Manuf. & 0.93 & 0.39 & 0.49 & 0.93 & 0.60 & 0.69 \\
\hline
\end{tabular}

a. Basic data are from worksheets provided by la Dirección de Estadistica de la Secretaria de Industria y Commercio in Mexico. The U.S. data for GDP by Industry in current dollars and full-time and part-time employees are from NIPA tables. 1970 Mexican value added was converted to 1975 pesos on the basis of the Mexican GDP deflator and then to 1975 US dollars on the basis of the 1975 exchange rate. The $1970 \mathrm{U} . S$. value added was converted from $1982 \$$ to 1975 using the U.S. GDP deflator. The TFP index is based on value added. The Mexican 1970 capital stock figures are based on capital invertido; the U.S. capital stock figures are from: Musgrave, John C., "Fixed Reproducible Tangible Wealth in the United States: Revised Estimates," Survey of Current Business, Vol. 66, No. 1, January, 1986, 51-75. Since the two concepts differ, the last three columns should be interpreted with caution. The productivity ratios are relative to the productivity levels of the whole U.S. industry.

b. Industries are classified by U.S. SIC code and include all four-digit SICs in each industry. See the Appendix for detailed Mexican industry codes included in each U.S. SIC code. 


\section{- $24-$ \\ Table 7}

Convergence in Productivity between Mexico and the U.S.:

Ratio of Mexican to U.S. Value Added per Employee, $1970 \& 1975^{\circ}$

\begin{tabular}{|c|c|c|c|c|c|c|}
\hline \multirow[b]{2}{*}{ Industries ${ }^{b}$} & \multicolumn{3}{|c|}{$\begin{array}{l}\text { All 4-Digit Mexican } \\
\text { Industries Included }\end{array}$} & \multicolumn{3}{|c|}{$\begin{array}{l}\text { Only 4-Digit Mex. Ind } \\
\text { With MNCs Included }\end{array}$} \\
\hline & 1970 & 1975 & Ratio & 1970 & 1975 & Ratio \\
\hline $\begin{array}{l}\text { 20-Food } \\
\text { 21-Tobacco } \\
\text { 22-Textile Mill } \\
\text { 23-Apparel } \\
\text { 24-Lumber \& Wood } \\
\text { 25-Furniture } \\
\text { 26-Paper } \\
\text { 27-Printing \& Publishing } \\
\text { 28-Chemicals } \\
\text { 29-Petroleum \& Coal } \\
\text { 30-Rubber \& Plastics } \\
\text { 31-Leather } \\
\text { 32-Stone, Clay \& Glass } \\
\text { 33-Primary Metals } \\
\text { 34-Fabricated Metals } \\
\text { 35-Non-Elec. Equip. } \\
\text { 36-Electric Equip. } \\
\text { 37-Transport Equip. } \\
\text { 38-Instruments } \\
\text { 39-Miscel. Manuf. }\end{array}$ & $\begin{array}{l}0.43 \\
0.39 \\
0.76 \\
0.67 \\
0.29 \\
0.73 \\
0.63 \\
0.41 \\
0.66 \\
0.24 \\
0.67 \\
0.52 \\
0.46 \\
0.67 \\
0.37 \\
0.45 \\
0.73 \\
0.53 \\
0.56 \\
0.35\end{array}$ & $\begin{array}{l}0.44 \\
0.45 \\
0.79 \\
0.51 \\
0.27 \\
0.59 \\
0.57 \\
0.44 \\
0.60 \\
0.21 \\
0.64 \\
0.43 \\
0.50 \\
0.66 \\
0.46 \\
0.51 \\
0.55 \\
0.38 \\
0.46 \\
0.35\end{array}$ & $\begin{array}{l}1.01 \\
1.15 \\
1.04 \\
0.76 \\
0.94 \\
0.81 \\
0.90 \\
1.06 \\
0.90 \\
0.87 \\
0.96 \\
0.82 \\
1.10 \\
0.98 \\
1.24 \\
1.14 \\
0.75 \\
0.72 \\
0.81 \\
0.99\end{array}$ & $\begin{array}{l}0.52 \\
0.39 \\
0.85 \\
0.68 \\
0.29 \\
0.73 \\
0.63 \\
0.41 \\
0.68 \\
0.29 \\
0.67 \\
0.53 \\
0.49 \\
0.67 \\
0.37 \\
0.45 \\
0.73 \\
0.53 \\
0.64 \\
0.36\end{array}$ & $\begin{array}{l}0.52 \\
0.45 \\
0.87 \\
0.52 \\
0.27 \\
0.59 \\
0.57 \\
0.44 \\
0.61 \\
0.22 \\
0.64 \\
0.43 \\
0.54 \\
0.66 \\
0.46 \\
0.52 \\
0.55 \\
0.38 \\
0.48 \\
0.36\end{array}$ & $\begin{array}{l}0.99 \\
1.15 \\
1.02 \\
0.76 \\
0.94 \\
0.81 \\
0.90 \\
1.06 \\
0.89 \\
0.75 \\
0.96 \\
0.82 \\
1.10 \\
0.98 \\
1.24 \\
1.15 \\
0.75 \\
0.72 \\
0.75 \\
1.00\end{array}$ \\
\hline Total Manuf. & 0.49 & 0.48 & 0.98 & 0.53 & 0.51 & 0.96 \\
\hline
\end{tabular}

a. Basic data are from worksheets provided by la Dirección de Estadistica de la Secretaria de Industria y Commercio in Mexico. The U.S. data for GDP by Industry in current dollars and full-time and part-time employees are from NIPA tables. 1970 Mexican value added was converted to 1975 pesos on the basis of the Mexican GDP deflator; 1975 pesos were then converted to 1975 US dollars on the basis of the 1975 exchange rate. The 1970 U.S. value added was converted from $1982 \$$ to $1975 \$$ using the U.S. GDP deflator.

b. Industries are classified by U.S. SIC code. The results in the three five columns are based on all four-digit SICs in each industry. The results in the last two columns are based on only the four-digit SICS in which MNCs are present in either 1970 or 1975. See the Appendix for detailed Mexican industry codes included in each U.S. SIC code. 
Table 8

Gonvergence of labor Productivity between Mexico and the U.S.: Ratio of Mexico to U.S. Value added per employee, 1965-B5*

\begin{tabular}{|c|c|c|c|c|c|c|c|c|}
\hline Industry. & 1965 & 1967 & 1970 & 1975 & 1977 & 1979 & 1982 & 1984 \\
\hline 20-Food & 0.42 & 0.50 & 0.51 & 0.52 & 0.62 & 0.56 & 0.47 & 0.51 \\
\hline $21-$ Tobacco & 0.35 & 0.54 & 0.55 & 0.92 & 1.00 & 1.04 & 0.87 & 0.75 \\
\hline 22-Textile Mill & NA & NA & 0.54 & 0.55 & 0.51 & 0.61 & 0.60 & 0.66 \\
\hline 23 -Appare 1 & NA & NA & NA & NA & NA & NA & NA & NA \\
\hline 24-Lumber \& Wood & 0.47 & 0.54 & 0.55 & 0.51 & 0.64 & 0.91 & 1.10 & 1.11 \\
\hline 25 -Furniture & NA & NA & NA & NA & NA & NA & NA & NA \\
\hline 26-Paper & NA & 0.56 & 0.67 & 0.68 & 0.60 & 0.61 & 0.61 & 0.68 \\
\hline $\begin{array}{r}\text { 27-Printing \& } \\
\text { Publishing }\end{array}$ & NA & NA & NA & NA & NA & NA & NA & NA \\
\hline 28 -Chemicals & 0.43 & 0.55 & 0.69 & 0.52 & 0.51 & 0.51 & 0.50 & 0.60 \\
\hline 29-Petroleum \& Coal & 0.22 & 0.51 & 0.25 & 0.34 & 0.25 & 0.26 & 0.15 & 0.37 \\
\hline 30-Rubber \& Plastics & 1.10 & 1.40 & 1.71 & 1.34 & 1.14 & 1.32 & 1.32 & 1.85 \\
\hline 31 -Leather & NA & NA & NA & NA & NA & NA & NA & NA \\
\hline $\begin{array}{l}\text { 32-Stone, Clay } \& \\
\text { Glass }\end{array}$ & 0.56 & 0.64 & 0.68 & 0.78 & 0.73 & 0.75 & 0.91 & 0.79 \\
\hline 33-Primary Metals & 0.55 & 0.58 & 0.68 & 0.64 & 0.58 & 0.62 & 0.64 & 0.83 \\
\hline 34-Fabricated Metals & NA & NA & 0.51 & 0.45 & 0.45 & 0.51 & 0.53 & 0.61 \\
\hline $\begin{array}{l}\text { 35-Machinery, exc. } \\
\text { Electrical }\end{array}$ & NA & 0.38 & 0.69 & 0.69 & 0.72 & 0.88 & 0.86 & 0.84 \\
\hline 36-Electric Equip. & NA & NA & 0.70 & 0.63 & 0.63 & 0.74 & 0.66 & 0.83 \\
\hline 37-Transport Equip. & NA & NA & NA & 0.53 & 0.43 & 0.61 & 0.59 & 0.57 \\
\hline 38 -Instruments & NA & NA & NA & NA & NA & NA & NA & NA \\
\hline 39-Misce1. Manuf. & NA & NA & NA & NA & NA & NA & NA & NA \\
\hline
\end{tabular}

a. Data for Mexican value added and average number of employees are from: United Nations, Industrial Statistics Yearbook, various years. The U.S. data for GDP by Industry in current dollars and full-time and part-time employees are from NIPA tables. Before 1977. Mexico value added is net of nonindustrial services purchased from others. For Mexico, current pesos were first converted into 1975 pesos using the Mexican GDP deflator and then converted to 1975 dollars using the actual 1975 exchange rate. For U.S., GDP in current dollars was converted into 1975 dollars using the U.S. GDP deflator. Because of a discontinuity in the Mexican value added series between 1976 and 1976, Mexican value added after 1977 was adjusted as: $\mathrm{VA}^{*}{ }_{\mathrm{t}}-\mathrm{VA}_{\mathrm{t}}\left(\mathrm{VA}_{76} \cdot\left(\mathrm{GO}_{77} / \mathrm{GO}_{76}\right) / \mathrm{VA}_{77}\right)$ where $V_{A}$ is value added and $G O$ is gross output. See Appendix for Mexican industries included in each U.S. SIC Gode. 
Table 9

Regression Analysis of Productivity Catch-Up between Mexican and U.S. Industries

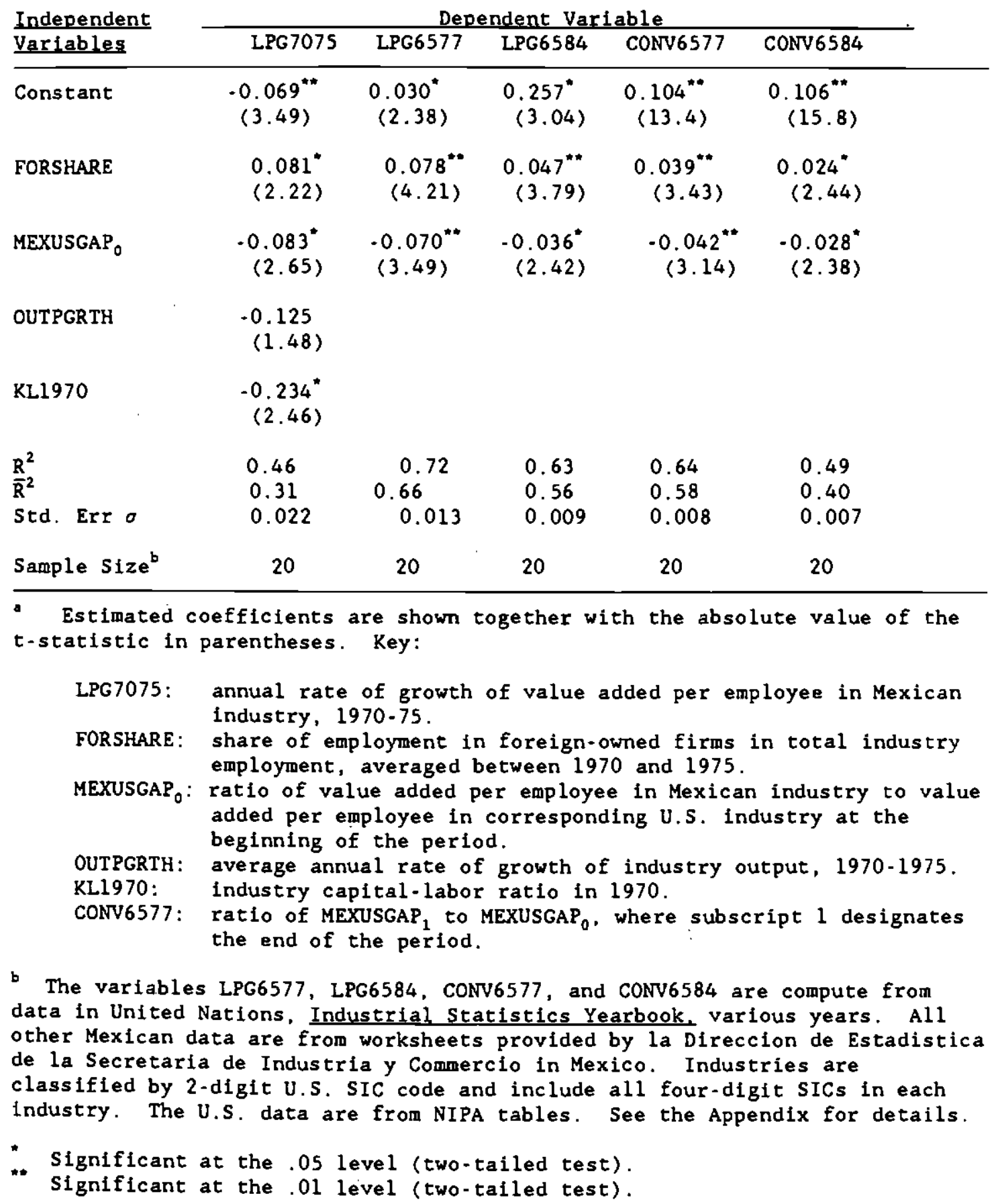


Appendix: Data Sources and Methods

I. Documentation for Mexican Data on Multinationsls and Domestic Firms.

A. Sources: The data on foreign and Mexican firms were provided by la Direccion de Estadistica de la Secretaria de Industria y Commercio In Mexico, and are from the Mexican Census of Manufactures, 1970 and 1975. The data are gathered at the plant level and cover the entire manufacturing industry, which is divided into 2304 -digit manufacturing industries. Because of missing information, 15 industries had to be discarded. In the regression analysis of productivity growth, on the 4-digit level, another 70 industries had to be discarded because of a change in the classification system between 1970 and 1975. In particular, all 4-digit industries in 1970 that were divided into two or more industry classed in 1975 were excluded.

Ownership is divided into three categories in the 1970 data: foreign, state-owned, and privately-owned. In 1975, it is divided into two categories: foreign and Mexican. Companies whose share are at least 15 percent foreign owned are classified as "foreign." If the Mexican state owns more than 49 per cent of a plant, it is defined as state-owned, even if foreigners own 15 per cent or more of its outstanding shares.

There are no capital stock figures that are comparable between 1970 and 1975. For 1970, we use capital invertido, which is the book value of net property, plant and equipment plus intangible capital. For 1975, we use activos fijos brutos, which is the gross value of property, plant, and equipment. Mexican deflators for GDP and gross fixed capital formation were derived from tables in United Nations, National Accounts Statistics: Main Aggregates and Detailed Tables, 1983.

B. Concordance Scheme between U.S, 2-Digit SIC codes and Mexican 4-Digit SIC Codes

2-Digit U.S. 1970 Mexican 4-Digit Codes

SIC Code All Ind. Ind, with MNCs

-..... - ...... -.............

20 - Food and Kindred Products

$\begin{array}{ll}2011 & 2011 \\ 2012 & 2012 \\ 2021 & 2021 \\ 2022 & 2022 \\ 2023 & 2023 \\ 2024 & 2024 \\ 2025 & 2025 \\ 2031 & 2032 \\ 2032 & 2034 \\ 2033 & 2041 \\ 2034 & 2051 \\ 2041 & 2055 \\ 2051 & 2058 \\ 2052 & 2059 \\ 2053 & 2061 \\ 2054 & 2062 \\ 2055 & 2071\end{array}$




$\begin{array}{ll}2056 & 2073 \\ 2057 & 2081 \\ 2058 & 2082 \\ 2059 & 2083 \\ 2061 & 2084 \\ 2062 & 2085 \\ 2071 & 2091 \\ 2072 & 2093 \\ 2073 & 2094 \\ 2081 & 2095 \\ 2082 & 2096 \\ 2083 & 2097 \\ 2084 & 2098 \\ 2085 & 2099 \\ 2091 & 2111 \\ 2092 & 2113 \\ 2093 & 2121 \\ 2094 & 2131 \\ 2095 & 2132 \\ 2096 & 2141 \\ 2097 & \\ 2098 & \\ 2099 & \\ 2111 & \\ 2112 & \\ 2113 & \\ 2121 & \\ 2123 & \\ 2131 & \\ 2132 & \\ 2141 & \\ \end{array}$

21 - Tobacco Manufactures

$\begin{array}{ll}2211 & 2211 \\ 2212 & 2212 \\ 2213 & 2213\end{array}$

22 - Textile Mill Products

$\begin{array}{ll}2311 & 2311 \\ 2312 & 2312 \\ 2313 & 2313 \\ 2315 & 2315 \\ 2316 & 2316 \\ 2319 & 2319 \\ 2321 & 2321 \\ 2322 & 2322 \\ 2323 & 2323 \\ 2331 & 2334 \\ 2333 & 2341 \\ 2334 & 2343 \\ 2341 & 2344 \\ 2342 & 2346 \\ 2343 & \end{array}$


2344

2345

2346

23 - Apparel and Other Textiles

$\begin{array}{ll}2421 & 2421 \\ 2422 & 2422 \\ 2423 & 2424 \\ 2424 & 2434 \\ 2425 & \\ 2426 & \\ 2427 & \\ 2431 & \\ 2432 & \\ 2433 & \\ 2434 & \\ 2439 & \end{array}$

24 - Lumber and Wood Products

$\begin{array}{ll}2511 & 2511 \\ 2512 & 2512 \\ 2521 & 2521 \\ 2522 & 2533 \\ 2531 & 2534 \\ 2533 & \\ 2534 & \end{array}$

25 - Furniture and Fixtures

$\begin{array}{ll}2612 & 2621 \\ 2621 & 3521 \\ 3521 & \end{array}$

26 - Paper and Allied Products

$\begin{array}{ll}2711 & 2711 \\ 2712 & 2712 \\ 2721 & 2721 \\ 2722 & 2722 \\ 2723 & 2723\end{array}$

27 Printing and Publishing

$\begin{array}{ll}2811 & 2811 \\ 2812 & 2812 \\ 2813 & 2813 \\ 2814 & 2814\end{array}$

28 - Chemicals and Allied Products

$\begin{array}{ll}3111 & 3111 \\ 3112 & 3112 \\ 3113 & 3113\end{array}$




$\begin{array}{ll}3121 & 3121 \\ 3122 & 3122 \\ 3131 & 3131 \\ 3132 & 3132 \\ 3141 & 3141 \\ 3151 & 3151 \\ 3161 & 3161 \\ 3162 & 3162 \\ 3171 & 3171 \\ 3172 & 3191 \\ 3191 & 3194 \\ 3192 & 3195 \\ 3193 & 3196 \\ 3194 & 3199 \\ 3195 & \\ 3196 & \\ 3199 & \end{array}$

29 . Petroleum and Coal Products

$\begin{array}{ll}3213 & 3213 \\ 3221 & 3221 \\ 3222 & \end{array}$

30 - Rubber and Misc. Plastics Products

$\begin{array}{ll}3011 & 3011 \\ 3012 & 3012 \\ 3013 & 3013 \\ 3181 & 3181\end{array}$

31 - Leather and Leather Products

$\begin{array}{ll}2411 & 2411 \\ 2412 & 2413 \\ 2413 & 2911 \\ 2911 & 2912 \\ 2912 & \end{array}$

32 - Stone, Clay and Glass Products

$\begin{array}{ll}3311 & 3311 \\ 3312 & 3312 \\ 3321 & 3321 \\ 3322 & 3323 \\ 3323 & 3324 \\ 3324 & 3329 \\ 3329 & 3341 \\ 3341 & 3342 \\ 3342 & 3351 \\ 3343 & 3352 \\ 3351 & 3354 \\ 3352 & \\ 3353 & \\ 3354 & \end{array}$


33. Primary Metal Industries

$\begin{array}{ll}3411 & 3411 \\ 3412 & 3412 \\ 3413 & 3413 \\ 3421 & 3421 \\ 3422 & 3422 \\ 3423 & 3423 \\ 3424 & 3424\end{array}$

34 - Fabricated Metal Products

$\begin{array}{ll}3511 & 3511 \\ 3512 & 3512 \\ 3513 & 3513 \\ 3514 & 3514 \\ 3517 & 3517 \\ 3531 & 3531 \\ 3541 & 3541 \\ 3542 & 3542 \\ 3543 & 3543 \\ 3544 & 3544 \\ 3545 & 3545 \\ 3546 & 3546 \\ 3547 & 3547 \\ 3549 & 3549 \\ 3987 & 3987\end{array}$

35 - Machinery, except Electrical

$\begin{array}{ll}3611 & 3611 \\ 3621 & 3621 \\ 3631 & 3632 \\ 3632 & 3641 \\ 3641 & 3651 \\ 3651 & 3652 \\ 3652 & 3653 \\ 3653 & 3654 \\ 3654 & 3655 \\ 3655 & 3656 \\ 3656 & 3659 \\ 3659 & \end{array}$

36 - Electric and Electronic Equipment

$\begin{array}{ll}3711 & 3711 \\ 3721 & 3721 \\ 3722 & 3722 \\ 3723 & 3723 \\ 3724 & 3724 \\ 3731 & 3731 \\ 3741 & 3741 \\ 3742 & 3742 \\ 3743 & 3743\end{array}$


$3749 \quad 3749$

37 - Transportation Equipment

$\begin{array}{ll}3811 & 3811 \\ 3821 & 3821 \\ 3831 & 3831 \\ 3832 & 3832 \\ 3834 & 3834 \\ 3841 & 3841 \\ 3842 & 3842 \\ 3843 & \end{array}$

38 - Instruments and Related Products

$\begin{array}{ll}3911 & 3911 \\ 3912 & 3912 \\ 3921 & 3921 \\ 3922 & 3922 \\ 3931 & 3931 \\ 3984 & \end{array}$

39 - Miscellaneous Manufacturing Industries

$\begin{array}{ll}3941 & 3942 \\ 3942 & 3951 \\ 3951 & 3961 \\ 3961 & 3971 \\ 3971 & 3981 \\ 3981 & 3982 \\ 3982 & 3983 \\ 3983 & 3986 \\ 3985 & 3988 \\ 3986 & \\ 3988 & \end{array}$

II. Documentation for Mexican industries included in U.N. data.

$\begin{array}{llc}\text { ISIC Industry Name } & \text { Beginning } \\ \text { 311/2 } & \text { of } & \text { Series } \\ \text { condensed and evaporated milk and milk powder } & 1965 \\ \text { canning of frults and vegetables } & 1965 \\ \text { canning of fish and shellfish } & 1965 \\ \text { wheat mills } & 1965 \\ \text { corn flour } & 1965 \\ \text { tea and instant coffee } & 1969 ? \\ \text { chewing gum } & 1969 ? \\ \text { biscuits and pastries } & 1965 \\ \text { yeast, baking powder, starch and similar products } & 1965 \\ \text { vegetable oils and margarine } & 1965 \\ \text { prepared foods for animals and fowls } & 1965 \\ \text { malt } & 1965 \\ \text { beer } & 1969 ?\end{array}$


soft drinks and henequen

manufacture of yarns

manufacture of cashmere textiles, shawls and similar products 1969 ?

manufacture of wool

331 manufacture of plywood, veneer and lamina

341 manufacture of pulp from fibre, paper and paperboard 1965 manufacture of articles of paperboard, including 1965

351 manufacture of cellulosic fibres and other artificial fibres 1965? manufacture of fertilizers 1965 ?

352 manufacture of matches and candles

soap, detergents and other cleaning compounds 1967

$\begin{array}{ll}\text { paints, varnishes and lacquers } & 1965\end{array}$

drugs and medicines 1975 ?

354 manufacture of coke and other coal products 1965

regeneration of lubricating oils including additives 1973

355 manufacture of tires and tubes $\quad 1965$

362 manufacture of sheet glass, glass fibres, safety glass, and 1965?

369 manufacture of hydraulic cement, brick, fire-proof 1965 ? partitions, refractory mortar

manufacture of asbestos products

371 manufacture of iron and steel tubes and rods 1967

founding, casting and rolling of iron and steel 1965

372 founding, refining, casting, extruding and drawing 1967 of copper and its alloys

casting, extruding and drawing of aluminum and manufacture 1965 ? of aluminum solders

381 manufacture of furniture and fixtures primarily of metal 1967? manufacture of crown caps and other cast and enamelled 1967? netal products

manufacture of containers and other products from tin-plate 1973

382 manufacture and assembly of agricultural machinery and 1965 equipment

manufacture and assembly of typing, computing and accounting machlnery 
and television

manufacture of condensers and batteries

manufacture and assembly of electrical apparatus and parts 1967

manufacture of other electronic equipment and apparatus 1975

384

manufacture and assembly of motor vehicles, including tractors for trailers

manufacture of bodies for motor vehicles

1965

manufacture of railroad equipment

? indicates exact year of inclusion cannot be determined from UN Yearbook From 1975 to 1984 , only 58 . out of the 225 4-digit Mexican manufacturing industries are included in the U.N. tabulations.

Concordance scheme between U,S, 2-Digit SIC Codes and UN 3-Digit ISIC Codes.

U.S. SIC

20 - Food and kindred products

21 - Tobacco manufactures

22 - Textile mill products

23 - Apparel and other textiles

24 - Lumber and wood products

25 - Furniture and fixtures

26 - Paper and allied products

27 - Printing and publishing

28 - Chemicals and allied products

29. Petroleum and coal products

30 - Rubber and misc. plastics products products

31 - Leather and leather products

32 - Stone, clay and glass products

33 - Primary metal industries

34 - Fabricated metal products

35 - Machinery, except electrical

36 - Electric and electronic equipment

37 - Transportation equipment

38 - Instruments and related products

39 - Miscellaneous manufacturing
UN ISIC

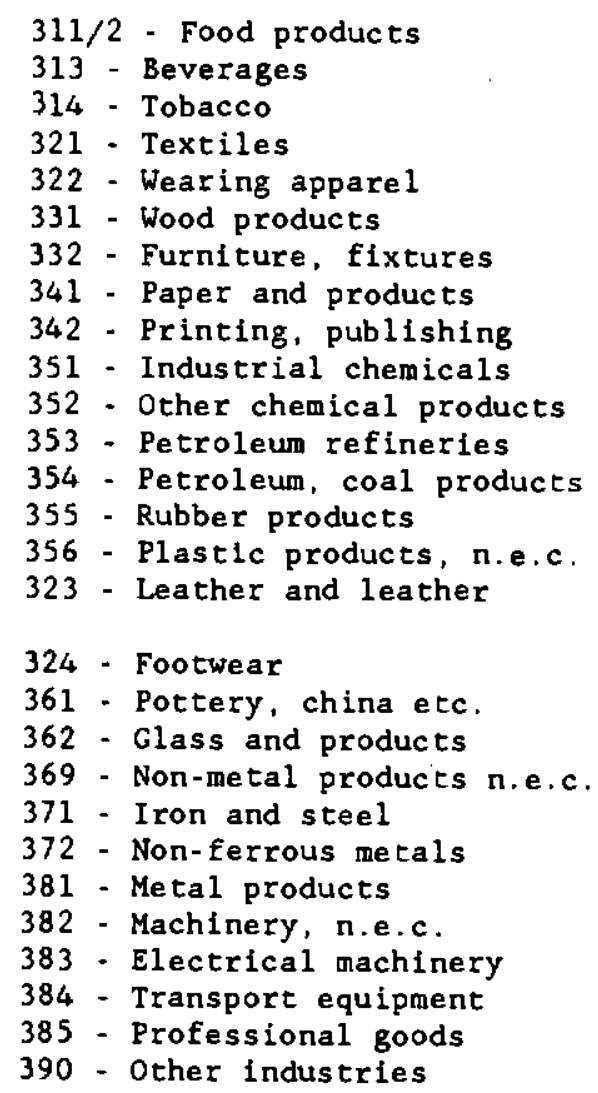

III. U,S, Data.

U.S. data are as follows: (i) GDP is from GDP by Industry in constant dollars. Table 6.02 of the National Income and Product Accounts: (ii) employment is from Full-time and part-time employees, Table 6.06 of the National Income and Product Accounts; (iii) capital stock figures are from: Musgrave, John C., "Fixed Reproducible Tangible Wealth in the United States: 
Revised Estimates," Survey of Current Business, Vo1. 66, No, 1, January, 1986, 51-75; and (Iv) U.S. deflators for GDP and gross fixed capltal formation were derived from tables in National Accounts, Main Aggregates, Volume I, 1960-84, OECD, Department of Economics and Statistics. 